REFERENCES

Blumgart, H. L., Riseman, J. E. F., Davis, D.; and Weinstein, A. A. (1935). Amer. Heart. J., 10, 596.

Ellis. A. W M.: Personal communication.

Levine, S. A., and Eppinger, E. C. (1935). Amer. Heart J., 10, 736

Lewis, Sir T. (1930). British Medical Journal, 1, 849.

Parkinson, J., and Clark-Kennedy, A. E. (1926). Quart. J. Med., 19,113 .

and Thomson, W. A. R. (1936). Lancet, 1, 16.

and Hoyle, C. (1937). Quart. J. Med., 30, 59.

Thompson, W. P., and White, P. D. (1936). Amer. Heart J., 12 , 641.

White, P. D. (1935). Lancet, 2, 539, 597.

\section{LUPUS VULGARIS}

\section{TREATMENT BY INTRADERMAL INJECTION OF HYDNOCARPATES}

BY

J. EDGAR WALLACE, M.D.,

Assistant Tuberculosis Officer, West Sussex County Council, late of Lancashire County Council

(With Special Plate)

The numerous methods which have been devised for the treatment of lupus vulgaris bear adequate testimony to the obstinate nature of this disease. For this reason the encouraging results that have recently been obtained by the intradermal injection of esters of hydnocarpus oil deserve more widespread attention than they have as yet received. Leprosy workers have for some years made increasing use of this method in dealing with cutaneous lesions, and the analogy between this disease and tuberculosis led to the account by Sir Leonard Rogers (1933) of a case of extensive lupus vulgaris successfully treated in this way.

Soon after this publication treatment was commenced in the present series of fifteen cases, and preliminary reports were issued in the succeeding two years (Wallace, 1934 and 1935). More recently Burgess (1935) has described a series of eleven cases, in which clinical cure was obtained in seven and improvement in the remaining four.

\section{Choice of Preparation}

The substance first used in the present investigation was that known as moogrol. This is prepared by esterizing the total acids of hydnocarpus oil, and consists of ethyl hydnocarpate and ethyl chaulmoograte, together with the esters of the other acids present in this oil. As reactions were sometimes unduly severe, iodized moogrol (containing $\mathbf{0 . 5}$ per cent. of iodine) was also tried. This, however, seemed less efficacious, and in addition produced in the scar a bluish-brown discoloration of considerable persistence.

Later, at the suggestion of Dr. T. A. Henry of the Wellcome Chemical Research Laboratories, both these forms were abandoned in favour of a third preparation, phenyl-ethyl hydnocarpate. The change proved to be a satisfactory one, as reactions became much less marked, and treatment could thus be advanced more rapidly. Phenyl-ethyl-hydnocarpate, which is therefore the preparation of choice, is now on the market under the trade name of eulykol (Burroughs Wellcome and Co.). Its less irritant effect has been made possible by eliminating the small uncrystallizable portion of the total fatty acids during the preparation of the ester.

\section{Technique}

Injections are made intradermally with an ordinary 1 c.cm. hypodermic syringe. fitted with an agla 240 needle
(B.W. and Co.). This is a $3 \mathrm{~mm}$. needle fitted with a guarded point. Patients attend weekly, and at each sitting a series of wheals $1 / 2 \mathrm{~cm}$. to $1 \mathrm{~cm}$. in diameter are raised in the lupus patches and nodules. The total amount of injection at any one time has not exceeded 1 c.cm., but Burgess, using phenyl-ethyl hydnocarpate exclusively, has injected as much as $5 \mathrm{c.cm}$. Reactions can be diminished by spacing the wheals as far apart as possible, and no area should be injected a second time until all inflammatory changes have subsided.

Lastly, it is important to avoid subcutaneous injection. This not only causes more severe diffuse reactions, but also fails to produce the desired effect, for, as Beatty (1932) points. out, the lupoid foci are mostly in the corium, and there is a layer of corial connective tissue between them and the subcutaneous tissue. These precautions are particularly to be observed in lesions around the eyes, where swelling of the loose tissues may be greater than elsewhere, and may cause some concern to the patient.

\section{Effect of Injections}

No general disturbance of any sort has been noted. The injection itself is practically painless, but during the next forty-eight hours a certain amount of redness and swelling appears, accompanied by a slight degree of pain and tenderness. The pain lasts for one or two days only, but the swelling may not subside for a week or longer.

As treatment continues a slowly progressive flattening of nodules and plaques occurs, together with a disappearance of scales and crusts. The granulation tissue between the lupoid areas diminishes. Tiny ulcers may appear in and around the site of injection. A varying degree of redness prevails, but gradually the active lesions are replaced by pale smooth scar tissue. Several months may elapse after the cessation of treatment before the final effect is seen. During this time the tendency to relapse is no less apparent than in other forms of lupus treatment. Careful observation is necessary to ensure that any recurrent nodules can be reinjected at the earliest possible moment.

The esters of hydnocarpus oil are absorbed very slowly from the skin, and their effect on lupoid tissue is continued long after the purely irritant reaction has worn off. For this reason one hesitates to regard the action entirely as a non-specific one, unless it be due, as Muir (1932) suggests, to the liberation of antigens.

\section{Summary of Cases}

The fifteen cases summarized in Tables I and II all attended a tuberculosis dispensary of the Lancashire County Council. Previous treatment had consisted of local and general artificial light therapy and occasional "spiking" with acid nitrate of mercury, but the lesions had mostly reached that curiously resistant stage where the disease appears to be neither advancing nor healing. All other forms of treatment were stopped at the commencement of the new method so that a fair trial could be made.

The length of treatment has varied in individual cases from six months to three years, although, in the longer cases, as the condition improved injections have frequently been spaced out at fortnightly or even monthly intervals. Treatment has been unduly prolonged in some cases, since considerable caution was exercised at the onset owing to the experimental nature of the method.

Progress has undoubtedly been more rapid than that made by artificial light treatment alone, but there is no reason why eulykol injections should not be supplemented by general carbon-arc baths, as in some of the cases 
TABLE I.-Lupus Vulgaris Treated with Intradermal Injections of Hydnocarpates (15 Cases)

\begin{tabular}{|c|c|c|c|c|c|c|c|c|}
\hline \multirow[t]{2}{*}{ Case } & \multirow[t]{2}{*}{ Age } & \multirow[t]{2}{*}{$\begin{array}{l}\text { Site of } \\
\text { Disease }\end{array}$} & \multirow[t]{2}{*}{$\begin{array}{l}\text { Dura- } \\
\text { of } \\
\text { Dis- } \\
\text { ease } \\
\text { in } \\
\text { Years }\end{array}$} & \multirow{2}{*}{\multicolumn{2}{|c|}{$\begin{array}{l}\text { Length of } \\
\text { Treatment }\end{array}$}} & \multicolumn{2}{|c|}{$\begin{array}{c}{ }^{*} \text { Approxi- } \\
\text { mate Size } \\
\text { of Active } \\
\text { Areas In } \\
\text { Square Centi- } \\
\text { metres }\end{array}$} & \multirow{2}{*}{$\begin{array}{l}\text { Condition at } \\
\text { Present Date }\end{array}$} \\
\hline & & & & & & Before & After & \\
\hline 1 & 35 & Neck & 10 & $9 \mathrm{~m}$ & onths & 27 & Nil & Quiescent (see Plate) \\
\hline 2 & 29 & Elbow & 14 & 3 ye & ars & 一 & Nil & Quiescent (see Plate) \\
\hline 3 & 35 & $\begin{array}{l}\text { Forehead } \\
\text { and fore- } \\
\text { arm }\end{array}$ & 24 & 3 & $"$ & - & - & Much improved \\
\hline 4 & 48 & Forearm & 40 & 3 & $"$ & 25 & 3 & $\begin{array}{l}\text { Quiescent except for } \\
\text { few nodules }\end{array}$ \\
\hline 5 & 18 & Arm & 10 & $6 \mathrm{~m}$ & onths & - & Nil & Quiescent \\
\hline 6 & 27 & $\begin{array}{l}\text { Face and } \\
\text { neck }\end{array}$ & 13 & $2 \frac{1}{2}$ & ears & 17 & Nil & Quiescent \\
\hline 7 & 12 & Thigh & 2 & & nonths & 9 & Nil & Quiescent \\
\hline 8 & 14 & Face & 10 & 10 & $"$ & - & Nil & Quiescent \\
\hline 9 & 39 & $\begin{array}{l}\text { Face and } \\
\text { neck }\end{array}$ & 25 & 12 & " & - & - & $\begin{array}{l}\text { Slight improvement. } \\
\text { Ceased treatment }\end{array}$ \\
\hline 10 & 14 & Thigh & 3 & 11 & $"$ & 25 & Nil & Quiescent (see Plate) \\
\hline 11 & 24 & $\begin{array}{l}\text { Neck and } \\
\text { wrist }\end{array}$ & 23 & $2 \frac{1}{2}$ & ears & 36 & 20 & $\begin{array}{l}\text { Much improved ; } \\
\text { wrist quiescent. } \\
\text { Ceased treatment }\end{array}$ \\
\hline 12 & 11 & $\begin{array}{l}\text { Cheek and } \\
\text { ear }\end{array}$ & 10 & 3 & $"$ & 3 & 2 & Slight improvement \\
\hline 13 & 29 & Face & 27 & & $"$ & 18 & 14 & Slight improvement \\
\hline 14 & 13 & Buttocks & 8 & 18 & nonths & 19 & 8 & $\begin{array}{l}\text { Much improved. } \\
\text { Ceased treatment }\end{array}$ \\
\hline 15 & 39 & Wrist & 27 & 15 & " & - & - & $\begin{array}{l}\text { Quiescent except for } \\
\text { few nodules }\end{array}$ \\
\hline
\end{tabular}

* Measurements are impracticable in some cases.

TABLE II.-Summary of Results (15 Cases) $\dagger$

\begin{tabular}{|c|c|c|c|c|c|c|}
\hline Quiescent, with pale healt & sca & & .. & .. & .. & .. \\
\hline Quiescent except for few & tive & dules & .. & .. & .. & -. \\
\hline Much improved $\quad$. & . & . & -. & $\cdots$ & -. & $\cdots$ \\
\hline Slight improvement only & . & .. & . & . & . & .. \\
\hline
\end{tabular}

† Three cases were abandoned for reasons unconnected with the treatment. Two of these (Cases 11 and 14) are included in the "much improved" group; the other (Case 9) in the "slight improvement only" group.

reported by Burgess. Reactions, too, are definitely less painful than those resulting from the usual caustic applications.

The cost is trivial, and the technique is so simple that the time factor at each session is reduced to a minimum. Patients as a whole have expressed satisfaction with the treatment and have attended with great regularity-a point of no little significance.

The intradermal injection of hydnocarpates, in the small number of cases so far available, has produced extremely encouraging results, and appears to offer certain advantages over other routine methods. Further clinical trials are awaited with interest and some degree of confidence.

I have to express my thanks to Sir Leonard Rogers and to Dr. T. A. Henry for their helpful interest. I am also indebted to Dr. G. Lissant Cox, central tuberculosis officer, and to Dr. E. H. A. Pask, consultant tuberculosis officer, both of the Lancashire County Council, for permission to publish these findings.

\section{REFERENCES}

Beatty, J. (1932). Practitioner, 128, 343.

Burgess, N. (1935). British Medical Journal, 2, 835.

Muir, E. (1932). Indian med. Gaz., 67, 121.

Rogers, L. (1933). British Medical Journal, 1, 47.

Wallace, J. E. (1934). Report for 1933, Central Tuberculosis Officer, Lancashire County Council. (1935). Ibid., 1934.

\section{IDIOPATHIC STEATORRHOEA REPORT OF A CASE ARISING IN ADULT LIFE \\ BY}

\author{
A. M. NUSSBRECHER, M.D., M.R.C.P. \\ Physician to Selly Oak Hospital, Birmingham \\ AND
}

\section{F. MORTON, B.Sc., A.I.C. Biochemist to the Hospital}

It is largely due to the work of Hess Thaysen that attention has recently been drawn to persistent diarrhoea found in adults in non-tropical countries. This condition has variously been called idiopathic steatorrhoea, non-tropical sprue, and "Gee-Thaysen's disease." Following Hess Thaysen's observations (1929) several important series of cases have been collected (Holmes and Starr, 1929; Bennett, Hunter, and Vaughan, 1932; Thaysen, 1935; Moore et al., 1936), whilst isolated instances, some of which bring new and interesting points to light, have also been recorded (Mackie, 1933 ; Fullerton and Innes, 1936). In the majority of the cases described the symptoms apparently originated in childhood, the diarrhoea and tetany recurring in adult life with intermediate periods of remission. In many of these instances there was evidence of rickets, infantilism, and gross bony deformities. Bennett, Hunter, and Vaughan (1932) concluded from their observations that the spontaneous occurrence of the disease in adult life, though not impossible, would be very rare. The later studies of Hess Thaysen (1935) have shown that onset of symptoms in adult life is not so infrequent as was formerly believed. The same author has stipulated as criteria of the disease the following four points. "(1) an abnormally large quantity of fat excreted in the faeces; (2) a normal or in some instances a slightly increased nitrogen excretion ; (3) a flat blood-sugar curve; and (4) a raised basal metabolic rate." Our own case conforms with the first three of these points, and reveals several other interesting features which make it worth recording.

\section{Case Record}

Clinical History.-The patient, a female 40 years of age, was quite well until seven years ago, when fourteen days after her last confinement she began to have "dysentery." She counted as many as twenty motions a day (an average of about fifteen), and frequently had to get up at night for bowel actions. She noticed the stools were offensive, greyish white in colour, frothy, and occasionally slimy but never bloodstained. She had been feeling weak and cold for a considerable time, and since May, 1936, had experienced cramps in the hands and feet and occasionally in the abdomen. These cramps occurred mostly on exertion, and also appeared to be precipitated by the menstrual periods. While they were present the fingers were drawn into the palms. Her feet and legs had swollen, especially after she had been up for some time, and her face had also swollen occasionally. She had lost weight from $10 \mathrm{st} .12 \mathrm{lb}$. three years ago to a present average of 8 st. Her periods have been regular, but the actual loss only slight.

The patient first came to our notice on August 14, 1936, when she was admitted to Selly Oak Hospital in an actual attack of tetany. Her condition then was as follows: Fairly well covered, colour good, no pigmentation, teeth in good condition. Slight oedema present over feet and lower parts of legs. Carpo-pedal spasm present. Trousseau's and Chvostek's signs positive. Marked hyperexcitability of all muscles, including those of the tongue. Slight glossitis noted. Heart and lungs normal. Blood pressure 120/80. Abdomen was distended and rectum somewhat ballooned. The urine showed no abnormality. 


\section{J. EDGAR WALLACE : TREATMENT OF LUPUS VULGARIS BY INTRADERMAL INJECTION OF HYDNOCARPATES}

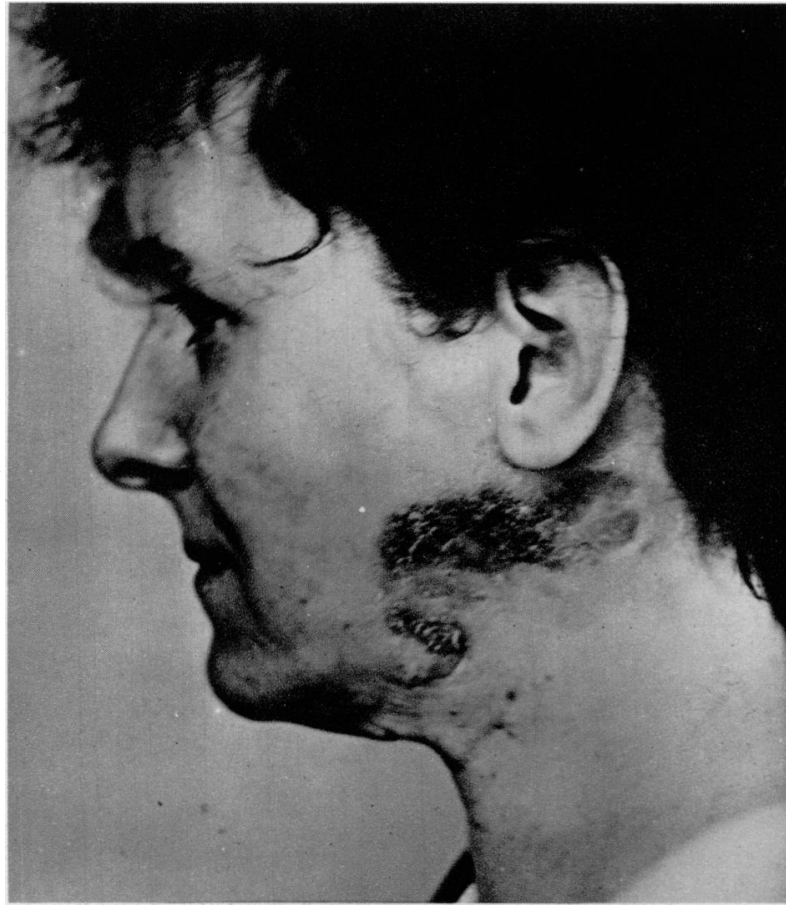

FIa. I.-Case 1. Lupus vulgaris of neck and face of 10 years' duration.

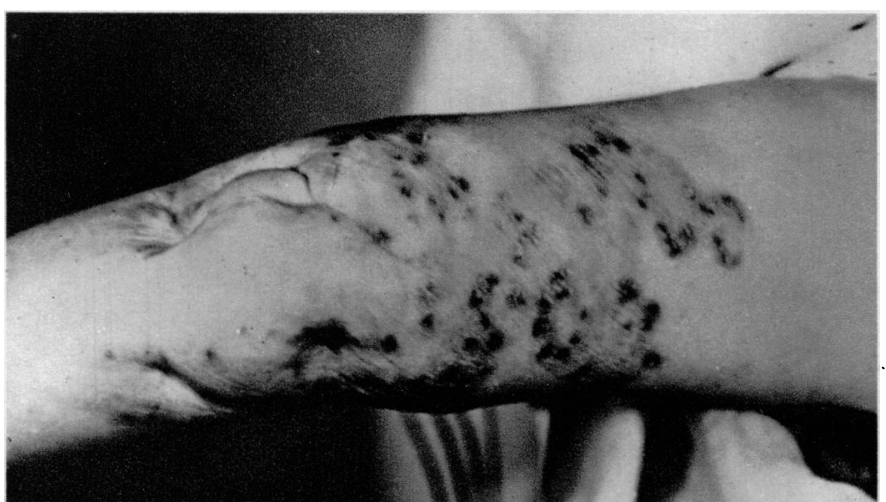

FiG. III.-Case 2. Lupus vulgaris in region of old tuberculous elbow, 14 years' duration. Before treatment in 1933.

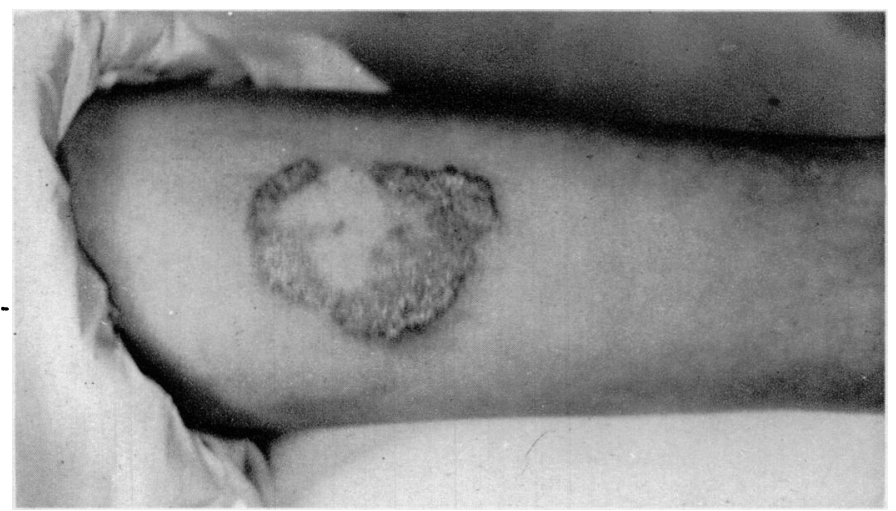

Fic. V.-Case 10. Lupus vulgaris of thigh of three years' duration. Before treatment. June, 1933.

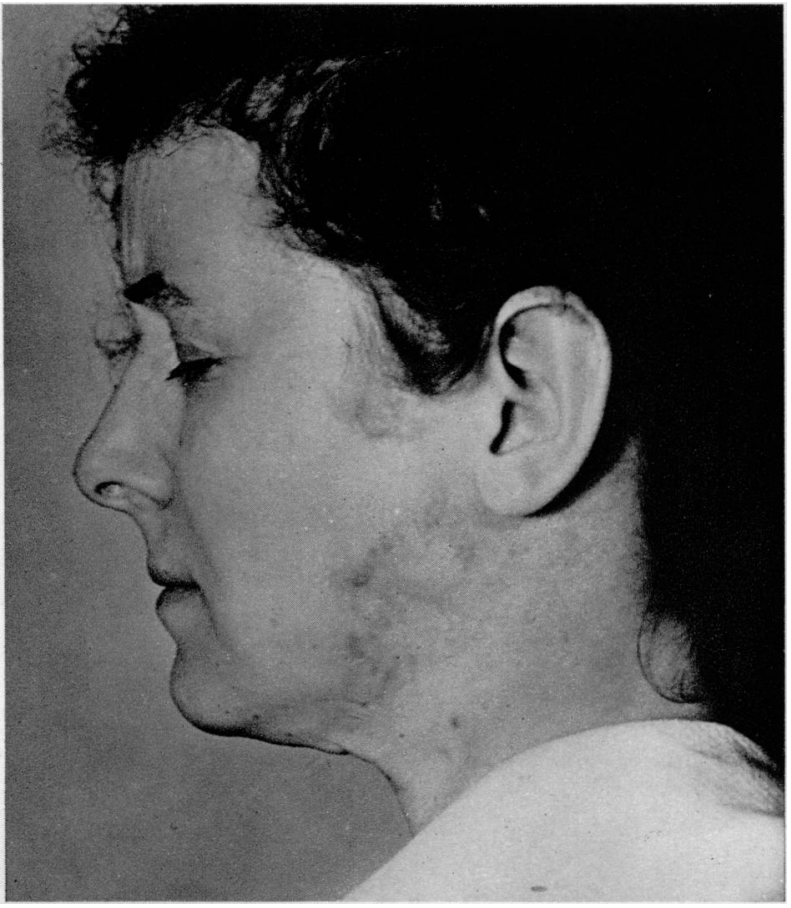

FiG. II.-Case 1. The same. 12 months after treatment.

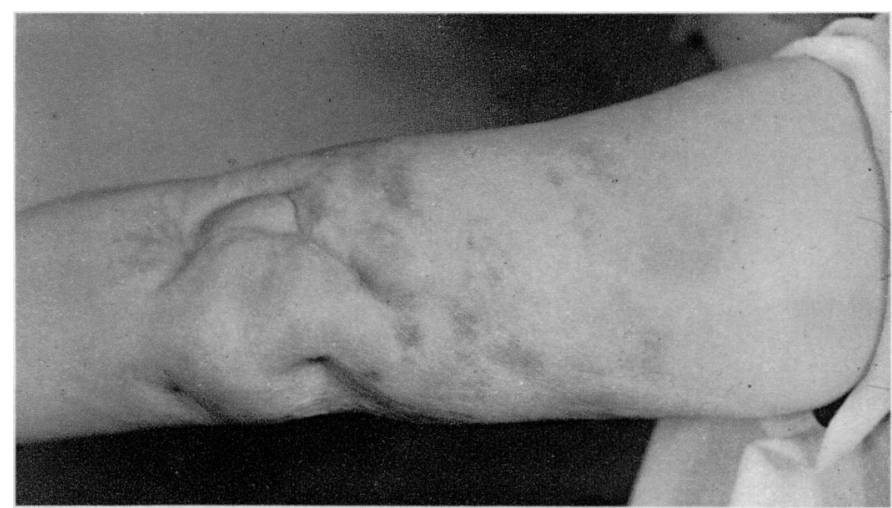

Fia. IV.-Case 2. The same in 1936 after treatment.

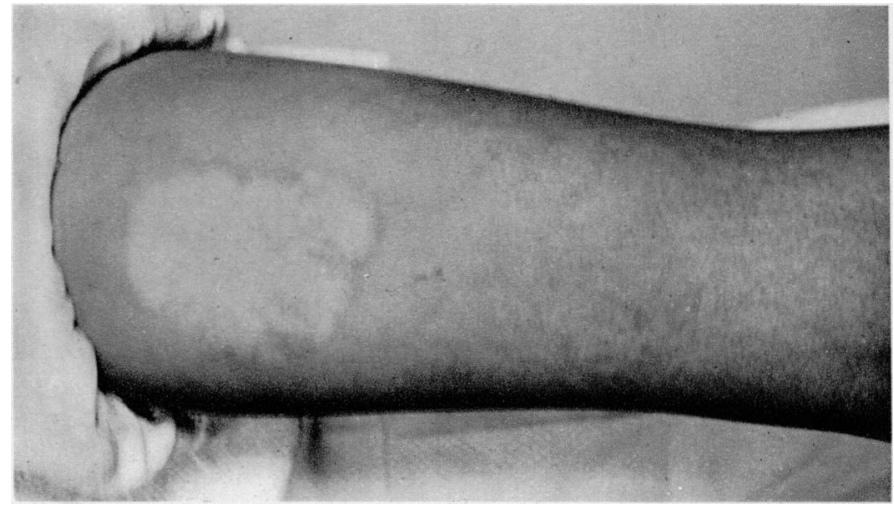

Fig. VI.-Case 10. The same in 1936, nearly two years after cessation of treatment 